\title{
Dividend Policy and Its Impact on Stock Price - A Study on Commercial Banks Listed in Dhaka Stock Exchange
}

\author{
Abdullah Al Masum \\ Senior Lecturer, Faculty of Business, ASA University Bangladesh, BANGLADESH
}

\begin{abstract}
How do dividend policy decisions affect a firm's stock price, is a widely researched topic in the field of investments and finance but still it remains a mystery that whether dividend policy affects the stock prices or not. There are those who suggest that dividend policy is irrelevant because they argue a firm's value should be determine by the basic earning power and business risk of the firm, in which case value depends only on the income (cash) produced, not on how the income is split between dividends and retained earnings and opponents of this statement called dividend is irrelevance, that investors care only about the total returns they receive, not whether they receive those returns in the form of dividends, capital gains or both.The results of researches conducted in various stock markets are different. There are many internal and external factors, which simultaneously affect stock prices and it is almost impossible to segregate the effect of each so the variations remain. This paper empirically estimates excess stock market returns for all the thirty banks listed in Dhaka Stock Exchange for the period of 2007 to 2011. Attempts are made to examine, what kind of relationship exists between dividend policy and stock market returns of private commercial banks in Bangladesh, and to what degree the returns on stocks can be explained by their respective dividend policy for the same period of time. Various theories related to dividend policy are tested in various parts of the world with different results and findings. Various other articles are reviewed, written in Bangladesh and abroad to see the significance of dividend policy on the stock prices and to compare the results of this research with those conducted earlier. Sample size is large i.e. all the listed commercial banks of Dhaka Stock Exchange so the results are reliable and valid. Panel data approach is used to explain the relationship between dividends and stock prices after controlling the variables like Earnings per Share, Return on Equity, Retention Ratio have positive relation with Stock Prices and significantly explain the variations in the market prices of shares, while the Dividend Yield and Profit after Tax has negative, insignificant relation with stock prices. Overall results of this study indicate that Dividend Policy has significant positive effect on Stock Prices.
\end{abstract}

Key words: Dividend Policy, Retention Ratio, Return on Equity, Stock Dividend, Cash Dividend, Market Price.

JEL Classification Code: D78; E64; H54; R53; G21. 


\section{INTRODUCTION}

Dividend policy is a major financing decision that involves with the payment to shareholders in return of their investments. Every firm operating in a given industry follows some sort of dividend payment pattern or dividend policy and obviously it is a financial indicator of the firm. Thus, demand of the firm's share should to some extent, dependent on the firm's dividend policy.

Dividend policy is one of the most widely researched topics in the field of finance but the question is whether dividend policy affects stock prices still remain debatable among managers, policy makers and researchers for many years. Dividend policy is important for investors, managers, lenders and for other stakeholders. It is important for investors because investors consider dividends not only the source of income but also a way to assess the firms from investment points of view. It is the way of assessing whether the company could generate cash or not. Many investors like to watch the dividend yield, which is calculated as the annual dividend income per share divided by the current share price. The dividend yield measures the amount of income received in proportion to the share price. If a company has a low dividend yield compared to other companies in its sector, it can mean two things: (1) the share price is high because the market reckons the company has impressive prospects and isn't overly worried about the company's dividend payments, or (2) the company is in trouble and cannot afford to pay reasonable dividends. At the same time, however, a high dividend yield can signal a sick company with a depressed share price. Dividend yield is of little importance for growth companies because, retained earnings will be reinvested in expansion opportunities, giving shareholders profits in the form of capital gains.

Selecting a suitable dividend policy is an important decision for the bank because flexibility to invest in future projects depends on the amount of dividends that they pay to their shareholders. If company pay more dividends then fewer funds available for investment in future projects. Lenders are also interested in the amount of dividend that a company declares, as more amounts is paid as dividend means less amount would be available to the company to payoff their obligation. So, the study will investigate the relationship between dividend policy and its impact on market performance of the share in the Dhaka stock exchange. In this study, researchers will examine with some real life sample (Commercial banks listed in Dhaka Stock Exchange) that whether the dividend policy has any effect on the firm's share price determinants as with compare to many in members other than the dividend payment pattern, researchers just focus on the specific factor; the dividend policy.

\section{LITERATURE REVIEW}

Gittman (2004, pp. 312) divided stock into two types, such as common stock and preferred stock. He also showed that dividends are the outcome of investment. So, common stocks are an ownership claim against primarily real or productive asset (Higgins, 1995), but he also said that if the company prospers, stockholders are the chief beneficiaries, if it falters, they are the chief losers. Smith (1988) presented that stocks are one of the most popular forms of investment. People buy stocks for various reasons: some are interested in the long-term growth of their investment by buying low priced stock of a new company in the hope of substantially growth of share price over the next few years. Another reason he suggested that in a well-established firm stockholders expect the stock growth will be stable over the long run. (Smith,1988).

Stockholders expect dividend but it is not promised (Gittman, 2004). Common stocks are hold by true owners of the business. Sometimes they are known as 'residual owners' as they receive whatever left after winding up of the company (Gittman, 2004; Higgins 1995). Another type of stock is known as publicly owned stock. Common stock owned by a broad group of 
unrelated investors or institutional investors is called as publicly owned stock. However, all common stock of a firm owned by a small group of investors is denoted as closely owned stock. When all the stock is owned by a single person is known as privately owned stock. Due to the limit of number of share, stock can be classified in to four types. Such as authorize share, outstanding share, treasury stock and issued stock (Gittman, 2004). Authorized shares represent the maximum number of shares a firm allows to issue. Outstanding shares are hold by public. Treasury stock is repurchased by firm itself and it is no longer considered as outstanding share. Issued shared are the shares that have been put into circulation. Recently stock repurchase option is very popular as it is able to increase stock value by decreasing outstanding stock number (Port, 1976). Port also suggested that firms should avoid issuing stock to pay dividend as they slow down company growth.

According to Short and Welsch (1990), Johns (1998) and Port (1976), a dividend is a usually distributed in cash form to stock holders of a corporation approved by the board of director. It may also include stock dividend or other forms of payment. A stock dividend represents a distribution of additional shares to common stockholders (Higgins, 1995).On the other hand, Ross et al. (2005) divided earnings into two parts; either it is retained or paid as dividend. Whereas Wild et al. (2001), Johns (1998) and Kieso et al. (2004) argued that retained earnings are the primary source of dividend distribution to the stockholder. Dividends are only cash payments regularly made by corporations to their stockholders (Johns, 1998). He also specified that they are decided upon the declaration by the board of the directors and can range from zero to virtually any amount the corporation can afford to pay.

Jones (2005) said that dividends are the only cash payment a stockholder receives directly from firm and these are the foundation of valuation for common stocks. Stock price response to an unexpected dividend change announcement is related to the dividend preferences of the marginal investor in that firm where other things remaining same (Denis et al., 1994). In addition, a company, which changes dividend policy, is expected to experience upward or downward trends in share returns (Gunasekarage et al., 2006). They also said that for the initiating firms, the share prices continued to rise even after the initial public offering (IPOs). Higgins (1995) said that if the company will have less money to invest, or it will have to raise more money from external sources to make the same investments stockholders claim on future cash flow, which reduces share price appreciation. Moreover, during dividend announcement period stock price also fluctuate due to announcement of dividend.Mulugetta et al. (2002) examined the impact of Standard and Poor's ranking changes on stock prices. In addition, Affleck-Graves \& Mendenhall (1992) found that stock price reacts after 8 days on average up to 54 days of such earning announcement.

With this believe, Hampton (1996) said that value of stock increase by more dividend and share remain undervalued by lower dividend policy. In addition, he also showed that there are two schools of thought regarding with the effect of dividend on stick price, one is dividends do not affect market price and the another one is dividend policies have profound effects on a firm's position in the stock market. . Benartzi et al. (1997), Ofer and Siegel's (1987) and Bae (1996) found a positive correlation between share price and dividend. Furthermore, Campbell and Shiller (1988) found a relationship between stock prices, earnings and expected dividends and he drives a conclusion that earnings and dividends is powerful in predicting stock returns over several years. Wilkieanalyzed a 76 months share price index and dividend announced. He found a correlation coefficient, which was under 0.7 for the period 76 months and he also get that the maximum value of the regression coefficient being reached after 79 months. Moreover, Shiller (1984, 1989) recommended investors in his study to buy the stocks when price is low relative to 
dividends and to sell stocks when it is high payoffs. On the other hand to their opinion, Jensen and Johnson (1995) suggested that, dividend cut results reduction in share price. More interesting matter is that if capital markets are perfect, dividends have no influence on the share price (Miller and Modgliani, 1961). Miller and Modgliani (1961) also states that if the market is imperfect, dividend may affect stock price.

\section{OBJECTIVES}

- To find the relation between the shares market price and the dividend policy of the banks.

- To analyze the factors affecting the market price of the banks share.

- To measure the impact of the bank's dividend policy on its shares market price.

\section{DefinITION OF VARIABLES}

In this study market price is taken as dependent variable. Dividend yield, retention ratio, earning per share, return on equity, and net profit after tax are used as independent variable. It is expected that all these variables have significant effect on stock price.

Market Price (MP):Market price is taken as dependent variable which is calculated by taking the average of high and low market prices of the shares while in the previous studied researchers like Rashid \& Rahman (2009), Nazir, Nawaz, Anwar, \& Ahmed (2010), Asghar, Shah, Hamid, \& Suleman (2011), Hussainey, K., Mgbame, C.O., \& chijoke-Mgbame, A.M. (2011) use price volatility as a dependent variable to see the effect of dividend policy on stock market prices.

Dividend Yield (DY): Dividend yield of a stock signifies how much a company pays dividend in relation to its stock price. It is calculated as a fraction of annual dividends paid by the company upon its stock price. Dividend yield is considered an important variable that is used by Allen \&Rachim (1996), Nishat and Irfan (2003), Rashid \& Rahman (2009), Nazir, Nawaz, Anwar, \& Ahmed (2010), Asghar, Shah, Hamid, \&Suleman (2011), Hussainey,Mgbame, \&Chijoke-Mgbame (2011) and it is significantly explaining the effect of dividend policy on stock market prices. All these researchers found positive relation between dividend yield and stock price.

Retention Ratio (RR): Retention Ratio is opposite to dividend pay-out ratio and is calculated by subtracting Total Dividend from Total Earnings and then dividing the resulting amount by Earnings.Pani (2008) used dividend to Retention Ratio to see its effect on Stock Prices and found positive relation between them. This ratio is previously ignored by the researchers and they used either dividend payout ratio or dividend yield ratio in their studies for explaining the variation in stock price.

Profit after Tax (PAT): Profit after tax is used a control variable. Pani (2008), Adesola \& Okwong (2009), Ahmed Javid (2009) and Al-Kuwari (2010) used profit after tax as independent variable in their studies and found positive relation between stock prices and profit after tax. They consider profit after tax as an important variable to explain the variation in stock prices.

Earnings Per Share (EPS): Earnings per share is the amount of earnings per each outstanding share of a company's stock.

Return on Equity (ROE): Return on Equity is calculated by dividing profit after tax with shareholders' equity. Liu \& Hu (2005), Raballe\&Hedensted (2008) and Ling, Mutalip, Shahrin, \&Othman (2008) used Return on Equity in their studies and found positive relation between Return on Equity and Stock Prices. 


\section{MetHodology}

The purpose of this research is to contribute towards a very important aspect of corporate financial management known as dividend policy with reference to banking industry, Bangladesh. Here the researchershow the relationship between dividend declaration practice and its impacts on shares market price of thirtycommercialbanks listed in Dhaka Stock Exchange (DSE) for the period of five years from 2007 - 2011. The selection of the study period was constrained by the factors, such as its enlistment year in DSE. The researcher only concentrated on the banks that have been listed in DSE on or before 2006 and also subject to availability of required data. The impact of dividend policy on company performance of banking industry is tested by panel data methodology. The panel data methodology use has certain benefits like using the assumption that the banks are heterogeneous, more variability, less co linearity between variables, more informative data, more degree of freedom and more efficient. The following section of the article will discuss the banks and variables included in the study, the distribution patterns of data and applied statistical techniques in investigating the relationship between dividend declaration policy and market price of the shares.

\section{MOdel SPECIFICATION}

In order to find out the relationship between different variables, first Pearson Correlation Coefficients are calculated. The impact of dividend policy on banksstock's market price is than investigated using the panel data of selected banks listed in Dhaka Stock Exchange (DSE) under the banking industry. Researchers develop an empirical framework, first used by Deloof (2003) and subsequently work of Padachi (2006). Our model is$M P$ it $=\beta_{0}+\beta_{1}\left(\right.$ DY $\left._{i t}\right)+\beta_{2}\left(R_{i t}\right)+\beta_{3}\left(P A T_{i t}\right)+\beta_{4}\left(E P S_{i t}\right)+\beta_{5}\left(R E_{i t}\right)+\eta_{t}+\lambda_{t}+\varepsilon_{i t}$

Where, Dependent Variable=Market Price (MP)

Independent Variable= Dividend Yield (DY), Retained Ratio (RR), Profit After Tax (PAT), Earnings Per Share (EPS),and Return on Equity (ROE).Here, MP is Market Price is used as a measure of bank's market performance. It is expected that Dividend Yield, Dividend per Share, Return on Equity, Return on Assets and Earning per Share will be positively associated to stock market prices i.e. increases in dividend, earning per share, return on equity, return on assets will result in increasing the stock market price of the banks while retention ratio and retained earningsper share has negative effect on stock price.nt measures the specific characteristics of each bank called unobservable heterogeneity, whereas $\lambda_{t}$ is a parameter for time dummy variables which is equal for all banks in each year but changes over time and $\varepsilon$ is the error term.

\section{FINDINGS}

The results of the impact of dividend policy and other explanatory variables on stock priceare presented in the following section. First, the descriptive analysis is presented followed by the Perason's correlation analysis to see the association between stock price and all independent variables. Panel data analysis with fixed effect and random effect modelsare also used in order to see the impact of dividend policy on the market price of the listed commercial banks in DSE.

\subsection{Descriptive Statistics}

Table 1 shows the detail of descriptive statistics of variables that affect the Market Price of the Private Commercial Banks listed in DSE for the period of 2007 to 2011. Market Price which is the dependent variable in the model ranges from 12.55 to 6129.70 with a mean value of 780.359 and standard deviation is 980.2878 . The first explanatory variable is dividend yield with a mean value of 0.04309 and a standard deviation of 0.033976 . Retention ratio which is 
the second explanatory variable ranges from 0 to 1.775 and its mean value and standard deviation is 0.598373 and 0.258545 respectively. Profit after tax which is the third explanatory variable has a minimum value Tk. -11017.5 million and maximum value Tk. 11185.86 million with mean 1293.129 and standard deviation2164.601. The fourth explanatory variable is Earnings per Share with a mean value of 32.007and a standard deviation of 130.4542. Finally, The fifth explanatory variableReturn on Equity shows the minimum value -0.298 and maximum value 1.04 with mean 0.19588 and standard deviation 0.112727 .

Table1: Descriptive Statistics

\begin{tabular}{|c|c|c|c|c|c|c|c|c|}
\hline & & \multirow[b]{2}{*}{ Maximum } & \multirow[b]{2}{*}{ Mean } & \multirow{2}{*}{$\begin{array}{c}\text { Std. } \\
\text { Deviation }\end{array}$} & \multicolumn{2}{|c|}{ Skewness } & \multicolumn{2}{|c|}{ Kurtosis } \\
\hline & & & & & Statistic & Std. Error & Statistic & Std. Error \\
\hline Market Price & 12.55 & 6129.7 & 780.359 & 980.2878 & 3.079107 & 0.20000 & 10.9352 & 0.39745 \\
\hline Dividend Yield & 0 & 0.134 & 0.04309 & 0.033976 & 0.571536 & 0.19934 & -0.39205 & 0.39615 \\
\hline Retention Ratio & 0 & 1.775 & 0.59837 & 0.258545 & -0.14755 & 0.19803 & 4.64764 & 0.39358 \\
\hline Profit After Tax & -11017.5 & 11185.86 & 1293.129 & 2164.601 & -1.83002 & 0.19803 & 16.4499 & 0.39358 \\
\hline Earnings Per Share & -881.4 & 1177 & 32.007 & 130.4542 & 2.211845 & 0.19803 & 55.7114 & 0.39358 \\
\hline Return on Equity & -0.298 & 1.04 & 0.19588 & 0.112727 & 2.192763 & 0.19803 & 22.8253 & 0.39358 \\
\hline
\end{tabular}

Source: Primary

\subsection{Correlation Analysis:}

Correlation matrix of all variables included in the analysis is presented in table 2 which is calculated based on data of 150 observations. The table shows that stock price is negatively associated with profit after tax, dividend yield and retention ratio, and stock price is positively associated with return on equity and earning per share. The correlation coefficients for dividend yield and retention ratio are significant.

Table2: Pearson Correlation Coefficient between variables of 30 private commercial banks (150 observations)

\begin{tabular}{|c|l|c|c|c|c|c|c|}
\hline & & MP & PAT & EPS & DY & RR & ROE \\
\hline \multirow{2}{*}{ MP } & Pearson Correlation & 1 & & & & & \\
\cline { 2 - 9 } & Sig. (2-tailed) &. & & & & & \\
\hline \multirow{2}{*}{ PAT } & Pearson Correlation & -.123 & 1 & & & & \\
\cline { 2 - 9 } & Sig. (2-tailed) & .137 &. & & & & \\
\hline \multirow{2}{*}{ EPS } & Pearson Correlation & .128 & .054 & 1 & & & \\
\cline { 2 - 9 } & Sig. (2-tailed) & .123 & .514 &. & & & \\
\hline \multirow{2}{*}{ DY } & Pearson Correlation & $-.2466^{* *}$ & $.180\left(^{*}\right)$ & .065 & 1 & & \\
\cline { 2 - 9 } & Sig. (2-tailed) & .003 & .029 & .435 &. & & \\
\hline \multirow{2}{*}{ RR } & Pearson Correlation & $-.183\left(^{*}\right)$ & $.3066^{* *}$ & $-.188\left(^{*}\right)$ & .078 & 1 & \\
\cline { 2 - 8 } & Sig. (2-tailed) & .026 & .000 & .021 & .347 &. & \\
\hline \multirow{2}{*}{ ROE } & Pearson Correlation & .140 & -.121 & $-.507\left(^{* *}\right)$ & .150 & .010 & 1 \\
\hline & Sig. (2-tailed) & .091 & .139 & .000 & .070 & .903 &. \\
\hline
\end{tabular}

** Correlation is significant at the 0.01 level (2-tailed).

* Correlation is significant at the 0.05 level (2-tailed).;Source: Primary

Data reflects significant correlations betweendividend yield and profitafter tax, retention ratio and profit after tax,retention ratio andearning per share,return on equity and earning per share. The correlation betweenearning per shareand profit after tax is (.054), dividend yield and profit after tax is (.180), dividend yield and earning per share is (.065), retention ratio and profit after tax is (.306), retention ratio andearning per share is (-.188), and return 
on equity and earning per share is (-.507). This has been taken into consideration in the regression analysis to avoid multi-colinearity problem.

\subsection{Empirical Model:}

Impact of dividend policy onstock price oftheCommercial Banksin Bangladesh is estimated using panel data analysis. Fixed Effect and Random Effect Model are used to validate the results after including the two independent variables Dividend Yield and Retention Ratio and control variables Profit after Tax, Earnings per Share, and Return on Equity. Table 3 exhibited the results of Fixed Effect Model and Table 4 exhibited the results of Random Effect Model.

Table 3: Fixed Effect Model:

\begin{tabular}{|l|l|l|l|l|ll|}
\hline Variables & Coef. & Std. Err. & $\mathbf{t}$ & P>t & [95\% Conf. Interval] \\
\hline _constant & 628.8372 & 309.8353 & 2.03 & 0.045 & 14.93839 & 1242.736 \\
\hline Return on equity & 2957.523 & 903.9123 & 3.27 & 0.001 & 1166.537 & 4748.509 \\
\hline Retention Ratio & 4.081349 & 329.5323 & 0.01 & 0.990 & -648.8447 & 657.0074 \\
\hline Dividend Yield & -6235.14 & 2153.408 & -2.90 & 0.005 & -10501.84 & -1968.441 \\
\hline Earnings Per Share & 5.704989 & 1.22275 & 4.67 & 0.000 & 3.282266 & 8.127712 \\
\hline Profit After Tax & -0.22544 & 0.044455 & -5.07 & 0.000 & -.3135182 & -.1373546 \\
\hline \hline \multicolumn{3}{|c|}{ Effect Specification } \\
$\begin{array}{l}\text { F statistics= 8.72 } \\
\text { Prob> F = } 0.0000\end{array}$
\end{tabular}

Source: Primary

Fixed Effect Model provides statistically better results than Random Effect Model. Dividend Yield is negatively related to Stock Price and the impact is significant in both the Fixed Effect and Random Effect Model. On the other hand, Retention Ratio is positively related to Stock Price in Fixed Effect Model but negatively related to Stock Price in Random Effect Model and the impact is insignificant in both of the models. The relation between Dividend YieldandStock Price is similar to Baskin (1989) but contrast to the results of Khan, K. I., et. al. (2011), and Nazir, Nawaz, Anwar, \& Ahmed (2010).Negative relation between Retention Ratioand Stock Price shows the shareholders want their banks to pay dividends and when the banks retain that amount to fulfill their internal needs; this will negatively affect the stock prices.

Two control variables Earnings per Share and Return on Equity are positively related to Stock Price, but Profit after Tax is negatively related to Stock Price in case of both Fixed Effect and Random Effect Models. The impact of Earning per Share on Stock Price is highly significant and the result is consistent with K. I., et. al. (2011) and Adesola \& Okwong (2009) who also found significant relation with Stock Price. The significant negative relation between Profit after Tax and Stock Price indicates that the share holders are not concerned with the profit of the banks; they are only concerned with the amount of dividend paid to them. On the other hand, significant positive relation between Return on Equity and Stock Price shows that when management efficiently utilizes the shareholders' funds and provides better return on investment, it will positively affect the Stock Prices.K. I., et. al. (2011) and Raballe \& Hedensted (2008) also found positive relation between Return on Equity and Stock Prices. 
Table 4: Random Effect Model:

\begin{tabular}{|c|c|c|c|c|c|}
\hline MP & Coef. & Std. Err. & $\mathrm{t}$ & $\mathrm{P}>\mathrm{t}$ & [95\% Conf. Interval] \\
\hline Constant & 517.949 & 272.2738 & 1.90 & 0.057 & $-15.69782 \quad 1051.596$ \\
\hline Return on equity & 3673.651 & 800.4578 & 4.59 & 0.000 & $2104.782 \quad 5242.519$ \\
\hline Retention Ratio & -32.52537 & 295.8994 & -0.11 & 0.912 & $-612.4774 \quad 547.4267$ \\
\hline Dividend Yield & -8397.262 & 2086.978 & -4.02 & 0.000 & $-12487.66-4306.861$ \\
\hline Earnings Per Share & 6.25943 & 1.11596 & 5.61 & 0.000 & $4.072189 \quad 8.446671$ \\
\hline Profit After Tax & -.1752699 & .0417759 & -4.20 & 0.000 & $\begin{array}{lll}-.2571492 & -.0933907 \\
\end{array}$ \\
\hline \multicolumn{3}{|c|}{$\begin{array}{ll}\text { F statistics }= & 13.32 \\
\text { Prob }>\text { F } & =0.0000\end{array}$} & \multicolumn{3}{|c|}{$\begin{aligned} \text { R-squared } & =0.6348 \\
\text { ed R-squared } & =0.5244\end{aligned}$} \\
\hline
\end{tabular}

Source: Primary

\section{CONCLUSION}

In the last decade stock market of Bangladesh went through many changes and huge ups and downs were seen. The economic crisis of the world in year 2009-11 also affected the market adversely. In the last couple of years the markets have again try to shown steady upward trend. All these fluctuations in the stock prices due to external factors, including international factors, make it difficult to check the impact of dividend policy. Here it is also pertinent to mention that stock markets of Bangladesh are mainly speculative and capital gains are mostly sought by investors, particularly individual investors. Institutions and long term investors give due consideration to dividends and dividend polices of companies, which is a large and significant portion of the total investment in the stock markets.The objective of the study was to analyse the relationship between Dividend Policy \& Stock Price of thirty commercial banks of Bangladesh listed in Dhaka Stock Exchange from 2007 to 2011. The empirical estimation based on the Fixed Effect and Random Effect Model show significant negative relation between Dividend Yield and Stock Price while Retention Ratio has a negative but statistically insignificant relationship with Stock Market Prices. This paper further shows that Return on Equity and Earnings per share have statistically significant positive impact on stock price and Profit after Tax has a significant negative impact on Stock Market Prices of the commercial banks of Bangladesh.

\section{REFERENCES}

Almeyda, G 1996, Money matters: reaching women microentrepreneurs with financial services, Inter-American Development bank/ UNIFEM.

Besley, S \& Brigham, EF 2008, Essentials of managerial finance, The Dryden Press, Orlando.

Chowdhury, TA \& Ahmed, K 2009, „Performance evaluation of selected private commercial banks in Bangladesh", International Journal of Business and Management, vol. 4, no. 4, pp. 86-97.

Dong, M., Robinson, C., \& Veld, C. (2005). Why Individual Investors Want Dividends. Journal of Corporate Finance, 1 (12), 121-158.

Gitman and Chad J. Zutter (Dec 7, 2011),"Principles of Managerial Finance,

Gorden, M. J. (1963). Optimal Investment and Financing Policy. The Journal of Finance, 18 (2), 264-272. 
Higgins, 1995, „Dividend changes and future profitability “, The Journal of Finance, vol. 56, no. 6, pp. 2111-33.

Nishat, M., \&Irfan, C. M. (2003).Dividend Policy and Stock Price Volatility in Pakistan.11th Pacific Basin Finance, Economics and Accounting Conference.

Ogden, JP 1994, "A dividend payment effect in stock returns", The Financial Review, vol. 29, no. 3, pp. 345-69.

Rankine, GW \&Stice, EK 1997, „Accounting rules and the signalling properties of 20 percent stock dividends", The Accounting Review, vol. 72, no. 1, pp. 23-46.

Smith,1988, "Dividend policy, growth, and the valuation of shares", The Journal of Business, vol. 34, no. 4, pp. 411-33.

The Dhaka Stock Exchange 2013, viewed 25 march 2013, <http://www.dsebd.org>.

Woolridge, JR 1983, „Dividend changes and security prices", The Journal of Finance, vol. 38, no. 5, pp. 1607-15.

World Bank 1996, Implementing the World Bank's gender policies, progress report no. 1, World Bank, Washington, DC.

Yilmaz, AK \&Gulay, G 2006, „Dividend policies and price-volume reactions to cash dividends on the stock market: evidence from the Istanbul Stock Exchange ", Emerging Markets Finance and Trade, vol. 42, no. 4, pp. 19-49.

Khan, K. I., Amir, M., Qayyum, A., Nasir, A., \& Khan, M.I. (2011). Can dividend decisions affect the stock prices: A case of dividend paying companies of KSE.International Research Journal of Finance and Economics, Volume 76(2011), pp. 67-74. 
